\title{
Electoral Governance and Human Rights Amid Pandemics in Africa: Key Lessons from the Early COVID-19 Experience
}

\author{
Mansha Mohee* \\ African Development Bank Group, Abidjan, Côte d'Ivoire \\ mansha_1830@yahoo.com
}

\begin{abstract}
Over 25 African countries had planned elections for 2020. In the face of the onset of the COVID-19 pandemic in March, states resorted to one of two courses of action: adherence to planned electoral timelines in the shadow of the outbreak, which largely led to record low voter turnouts and hastened the spread of the virus; or adjourning elections with ill-defined election programming, constitutional tensions and unrest over delayed polls. The global health crisis not only frustrated the organization of the electoral process but set severe challenges to democracy, the rule of law and human rights in the region at a time of landmark elections, notably in Ethiopia, Burundi and Malawi. This article analyses initial state responses in electoral administration in light of international electoral norms, and interrogates the role of national and regional mechanisms in securing safe, inclusive, timely, free and fair elections amid new infectious disease outbreaks.
\end{abstract}

\section{Keywords}

Electoral governance, African elections, COVID-19 pandemic, human rights, free and fair elections

\section{INTRODUCTION}

The COVID-19 outbreak had a disruptive effect on the implementation of the African electoral calendar in 2020, which included presidential, parliamentary or local elections across more than 25 countries. ${ }^{1}$ Significantly, some highly charged elections had been foreseen to mark seismic moments in African politics. Parliamentary elections in Ethiopia, scheduled for August 2020, were set to be the first competitive elections after the democratic transition in 2018 and a test of the reformist agenda of Prime Minister Abiy Ahmed. The presidential election rerun in Malawi in June was due to follow the

* Research and development consultant, African Development Bank Group.

1 "2020 African election calendar" (January 2021, Electoral Institute for Sustainable Democracy in Africa), available at: <https://www.eisa.org/calendar2020.php> (last accessed 23 August 2021). 
Constitutional Court's annulment in February of the May 2019 poll results, upon findings of widespread and systematic irregularities and subsequent violent protests that had lasted for months. In Burundi, the presidential election in May was coming after a protracted political crisis that had endured since 2015 due to Pierre Nkurunziza's contested third term in office, which had led to an attempted coup, mass demonstrations and sanctions from the country's main international donors. Presidential elections in Côte d'Ivoire in October were fraught with the precedent of turbulent elections in 2011 and concerns over creeping authoritarianism.

In the wake of the pandemic sweeping across the continent in March, the National Electoral Board of Ethiopia announced the indefinite adjournment of elections. ${ }^{2}$ Shortly thereafter, Parliament approved the extension of the terms of the sitting prime minister and federal and regional assemblies until international health institutions had evaluated that the COVID-19 threat had subsided. ${ }^{3}$ Exasperated by an apparent lack of consultation by the federal government, long-standing tensions with Tigray State intensified as it held regional elections in September, flouting the government's postponement of elections and escalating a drawn-out crisis that has since displaced millions. Elections were eventually announced in December, for June 2021, with the omission of Tigray, where timelines were expected to be defined once conditions were suitable for the conduct of elections. ${ }^{4}$ Conversely, amid claims of electoral harassment, the election rerun in Malawi was held as planned and was hailed as a milestone for being the first to lead to the defeat of an incumbent. ${ }^{5}$ In Burundi, elections were also held as planned despite the pandemic, but independent international observer missions were denied access, apart from the East African Community, which was told 12 days before the polls of the requirement for two-weeks' quarantine on arrival. ${ }^{6}$ In the lead-up to the elections, the government declared the country representative of the World Health Organization (WHO) and three of its experts persona non grata and suspended diaspora voting in embassies to limit the spread of the

2 The National Electoral Board of Ethiopia released the announcement on Facebook: <https:// www.facebook.com/414693405979601/photos/a.430204581095150/659503991498540/? type $=3 \&$ theater $>$ (last accessed 23 August 2021).

3 "Ethiopian Parliament allows PM Abiy to stay in office beyond term" (10 June 2020) Al Jazeera, available at: <https://www.aljazeera.com/news/2020/06/ethiopian-parliamentpm-abiy-stay-office-term-200610195337702.html> (last accessed 23 August 2021).

4 See National Electoral Board of Ethiopia's announcement on Twitter: <https://twitter.co m/NEBEthiopia/status/1342429738036580352/photo/1> (last accessed 23 August 2021).

5 "Opposition wins rerun of Malawi's presidential election in historic first" (27 June 2020) The Guardian, available at: <https://www.theguardian.com/world/2020/jun/27/oppos ition-wins-rerun-of-malawis-presidential-election-in-historic-first> (last accessed 23 August 2021).

6 "Burundi ruling party candidate wins presidential election" (26 May 2020) africanews, available at: <https://www.africanews.com/2020/05/25/burundi-polls-ruling-party-oncourse-for-landslide-victory//> (last accessed 23 August 2021). 
virus in respective countries. ${ }^{7}$ In Côte d'Ivoire, voter registration was delayed and polls were expected to be deferred to $2021 .^{8}$ Meanwhile President Alassane Ouattara abruptly opted to run for a third term whereas most of his political opponents were precluded from standing for election. Only four of over 70 candidacies were upheld by the Constitutional Court. ${ }^{9}$ Prominent rival Guillaume Soro was sentenced to 20 years in prison for corruption in April. The government withdrew direct access to the African Court of Human and Peoples' Rights (African Court) when the latter ordered the suspension of an arrest warrant against Soro. ${ }^{10}$ After a landslide victory for Ouattara, protests were quelled and the opposition's attempt to form a parallel government collapsed after security forces surrounded the opposition leader's house. ${ }^{11}$

Much is at stake for democratic governance in the region, which had made important strides in recent years amid a hopeful fourth wave of democratization. ${ }^{12}$ Data on "democratic elections" and "mechanisms for orderly transfers of power" feature as two of the most improved indicators in the Ibrahim Index of African Governance for the period $2010-17 .^{13}$ The index also indicates that elections have become freer and fairer, advancing on average 0.68 points per

7 "Burundi: Intimidation, arrests during elections" (1 June 2020, Human Rights Watch), available at: <https://www.hrw.org/news/2020/06/01/burundi-intimidation-arrestsduring-elections> (last accessed 23 August 2021).

8 "Coronavirus and Africa: Towards a postponement of the presidential election in Ivory Coast?" (21 April 2020, Institut Montaigne), available at: < https://www.institutmo ntaigne.org/en/blog/coronavirus-and-africa-towards-postponement-presidential-electionivory-coast> (last accessed 23 August 2021).

9 Decision no CI-2020-EP-009/14-09/CC/SG, 14 September 2020 on the publication of the definitive list of candidates for election as president of the republic on 31 October 2020, Côte d'Ivoire Constitutional Court.

10 Guillaume Kigbafori Soro and Others $v$ The Republic of Côte d'Ivoire African Court, appln no 012/2020.

11 "Ivory Coast: Security forces surround homes of opposition leaders" (4 November 2020) Al Jazeera, available at: <https://www.aljazeera.com/news/2020/11/4/i-coast-securitycranked-up-after-victory-of-president-ouattara (last accessed 23 August 2021).

12 See G Lynch and G Crawford "Democratization in Africa 1990-2010: An assessment" (2011) 18/2 Democratization 275 for a recent appraisal of the state of democratization on the continent. After the Arab Spring in the early 2010s, some commentators posit a fourth phase of democratization.

13 "Ibrahim index of African governance" (Mo Ibrahim Foundation), available at: <http:// iiag.online/> (last accessed 23 August 2021). The score on the "democratic elections" indicator ("the extent to which executive and legislative elections are free and fair, including impartiality of the electoral laws and framework") increased from 43.2 in 2010 to 50.6 in 2017; that of the "mechanisms for orderly transfers of power" indicator ("clarity of established and accepted constitutional mechanisms for the orderly transfer of power from one government to another") increased from 33 to 40.1. See also I Schultes "A strain on democracy? African elections and COVID-19" (Mo Ibrahim Foundation), available at: <https://mo.ibrahim.foundation/sites/default/files/2020-05/elections-covid19_0.pdf> (last accessed 23 August 2021). 
year and showing marked progress in at least 33 African countries. ${ }^{14}$ The global health crisis has set unprecedented challenges to the electoral process and led governments into a balancing act between health and democratic imperatives, imperilling the gains acquired in the last decade. ${ }^{15}$ Hard-hit economies have been strained by logistical hitches, technical adjustments and increased election costs. ${ }^{16}$ Political parties have been made more dependent on public funding, which has been reduced in favour of healthcare and relief programmes. Travel restrictions and border shutdowns have upended the deployment of international observation missions and the international procurement of election materials. ${ }^{17}$ Measures taken to curb the spread of the virus, such as restrictions on free movement and public assembly, have invariably affected the democratic process by limiting political engagement. The COVID-19 environment has also been prone to exacerbate political polarization, as governments use the pandemic to advance partisan agendas. Emergency powers and the decline in checks and balances afforded by the crisis have given free rein to political expediency, opportunist strongholds on power and democratic backsliding. Reports since the start of the outbreak have indicated a spate of legal amendments stifling free speech and civic space, introducing new penalties against dissent and suspending newspapers. ${ }^{18}$ The outbreak has also sparked discourse, notably in South Africa, on the value of the democratic model when responding to a health crisis, ${ }^{19}$ likely to embolden authoritarian regimes in their responses but also to favour them in polls.

As the pandemic unfolded on the continent and in light of uncertainties spurred by the novel disease, some governments staged elections as planned while others readjusted electoral timelines or postponed elections

14 Ibrahim Index of African Governance: Index Report (2018, Mo Ibrahim Foundation) at 40, available at: <https://mo-s3.ibrahim.foundation/u/2018/11/27173840/2018-Index-Report. pdf> (last accessed 23 August 2021).

15 For an initial assessment, see T Landman and L Di Gennaro Splendore "Pandemic democracy: Elections and COVID-19" (2020) 23/7-8 Journal of Risk Research 1060, available at: <https://doi.org/10.1080/13669877.2020.1765003> (last accessed 23 August 2021).

16 "COVID-19 disrupts elections across Africa" (26 May 2020, International Foundation for Electoral Systems), available at: <https://www.ifes.org/news/covid-19-disrupts-electionsacross-africa $>$ (last accessed 23 August 2021).

17 B Bam "COVID-19: An opportunity to reflect on approaches to and the conducting of elections in Africa" (10 June 2020, ACCORD), available at: <https://www.accord.org. za/analysis/covid-19-an-opportunity-to-reflect-on-approaches-to-and-the-conducting-ofelections-in-africa/> (last accessed 23 August 2021).

18 See "COVID-19 civic freedom tracker" (International Center for Not For Profit Law), available at: <https://www.icnl.org/covid19tracker/?location=\&issue=9\&date=\&type=> (last accessed 23 August 2021).

19 S Friedman "Unravelling why some democracies - but not all - are better at fighting pandemics” (14 April 2020) The Conversation, available at: <https://theconversation.com/ unravelling-why-some-democracies-but-not-all-are-better-at-fighting-pandemics-136267> (last accessed 23 August 2021). 
indefinitely. ${ }^{20}$ Notably, as part of emergency response frameworks, at least 12 countries postponed national or local elections, including Ethiopia, The Gambia, Kenya, Nigeria, Tunisia, Uganda and Zimbabwe. Five countries (Guinea, Mali, Benin, Burundi and Malawi) held elections as originally planned in the thick of the crisis. Timelines of some elections scheduled for the second half of 2020 were maintained at the time of the outbreak, but adjournments were considered likely in the lead up to elections, notably in respect of general elections in Ghana (where voter registration and staff training had been stalled), ${ }^{21}$ senatorial elections in Liberia (where authorities were struggling to secure electoral material), ${ }^{22}$ transitional elections in Somalia (which also faced significant preparatory challenges) ${ }^{23}$ and votes in Chad, Central African Republic and Gabon, which were all overwhelmed with security challenges conflated by the pandemic. In general, decision-making was unilateral, concentrated in the executive, with little or no consultation with health authorities, opposition parties and the electorate, and without transparency over deliberations. ${ }^{24}$ Where elections were held, countries registered lower voter turnout than in previous elections, in most instances raising concerns over public participation, disenfranchisement of marginalized communities and the legitimacy of results. ${ }^{25}$ Shifts in electoral cycles also triggered worrying repercussions for constitutionalism, peace and security. ${ }^{26}$

20 For a tracker of government responses to scheduled elections since the outbreak, see "Global overview of COVID-19: Impact on elections" (International Institute for Democracy and Electoral Assistance), available at: <https://www.idea.int/newsmedia/multimedia-reports/global-overview-covid-19-impact-elections> (last accessed 23 August 2021). See also for an overview of responses in Africa: E Asplund and $O$ Akinduro "The COVID-19 electoral landscape in Africa" (19 May 2020, International Institute for Democracy and Electoral Assistance), available at: <https://www.idea. int/news-media/news/covid-19-electoral-landscape-africa> (last accessed 23 August 2021). Notably, no African government resorted to online or remote voting. The cancellation of elections due to economic crises and strained resources was also anticipated by commentators but was not announced by any African government.

21 “COVID-19: Ghana's Electoral Commission postpones new voters' registration" (25 March 2020) APAnews, available at: <http://apanews.net/en/news/covid-19-ghanas-electoralcommission-postpones-new-voters-registration> (last accessed 23 August 2021).

22 See M Dahn "Liberia: NEC proposes postponement of 2020 special Senatorial election" (6 May 2020) Liberia Public Radio, available at: <https://liberiapublicradio.com/2020/ 05/06/nec-proposes-postponement-of-2020-special-senatorial-election/> (last accessed 9 September 2021).

23 "Impossible to hold 2020 polls: Somalia election boss" (27 June 2020) africanews, available at: <https://www.africanews.com/2020/06/27/somalia-postpones-2020-elections//> (last accessed 23 August 2021).

24 "Democracy must not become the silent victim of the coronavirus pandemic" (19 May 2020, open letter from Kofi Annan Foundation), available at: <https://www.ko fiannanfoundation.org/app/uploads/2020/06/fa3f4170-kofiannanfoundation_openletter_ en_final_10may2020.pdf> (last accessed 23 August 2021).

25 For an overview of the impact of country responses on democracy and human rights issues in Africa and more broadly, see COVID-DEM Infohub, available at: <https://www. democratic-decay.org/covid-dem> (last accessed 9 July 2021).

Ibid. 
This article provides a study of preliminary African responses in electoral administration during the onset of the COVID-19 pandemic. In particular, it seeks to investigate the threat posed to democracy, the rule of law and human rights as experienced in Africa since the outbreak, as well as key questions to be considered in respect of enhanced preparedness for future crises in the African context. The article is in three sections. The first studies the human rights implications of the approaches taken by African governments in the first year of the outbreak. The second examines the normative and institutional framework of electoral governance on the continent to underline state duties and regional mechanisms, relevant to the conduct of elections under the backdrop of pandemics. Drawing from an analysis of emerging prospects and challenges, the third section identifies vital national and regional mitigation efforts for reconciling the conduct of elections with human rights considerations amid new infectious disease outbreaks. The article concludes by presenting the salient takeaways gleaned from early state and regional responses in electoral administration in Africa.

\section{STATE RESPONSES: HUMAN RIGHTS IMPLICATIONS}

National efforts to manage the global health crisis can detrimentally affect democracy, the rule of law and human rights. ${ }^{27}$ State responses in electoral administration, in particular, carry unique human rights implications. In the African context, along with the health risks incidental to responses, decisions to hold or postpone elections mostly followed other repressive measures intended to curtail civic space and tended to aggravate extant human rights violations or security and humanitarian crises, leading to political turmoil and peace and security challenges. This section documents the human rights impact of state responses in electoral administration since the onset of the pandemic.

\section{Public health}

Despite having imposed lockdowns, curfews or bans on large public gatherings, governments and politicians flouted mitigation measures when

27 CA Corao "Challenges that the COVID-19 pandemic poses to the rule of law, democracy and human rights" (Max Planck Institute for Comparative Public Law and International Law research paper series no 2020-23, June 2020), available at: <https://papers.ssrn. com/sol3/papers.cfm?abstract_id=3638158> (last accessed 23 August 2021). For a general overview of the impact of COVID-19 on human rights, see "The pandemic democratic violations index" (V-Dem Research Institute, University of Gothenburg), available at: <https://www.v-dem.net/en/analysis/PanDem/> (last accessed 23 August 2021); "Global monitor of COVID-19's impact on democracy and human rights" (Institute for Democracy and Electoral Assistance / European Commission), available at: <https:// www.idea.int/gsod-indices/\#/indices/world-map?covid19=1> (last accessed 23 August 2021); and "Parliamentary responses during the COVID-19 pandemic: Data tracker" (INTER PARES), available at: <https://www.inter-pares.eu/inter-pares-parliamentary-datatracker> (last accessed 23 August 2021). 
running campaigns as well as on polling day. In Malawi, a state of national disaster was declared in March and large gatherings were limited to 100 attendees. Yet, since the start of the campaign trail in May when candidates handed in their nomination papers, both the ruling party and opposition parties led political rallies attended by thousands of supporters, most of whom did not wear face masks or observe social distancing. ${ }^{28}$ Infections accelerated rapidly during the electoral period and, by the swearing-in of the new president, the number of COVID-19 cases had more than doubled within two weeks. ${ }^{29}$ Similarly, in Benin, although the National Independent Electoral Commission proscribed public meetings of more than 50 and stipulated media campaigning only, rallies were held unabated, generally unchecked by the security forces. ${ }^{30} \mathrm{~A}$ sanitary cordon put in place to limit movement in the municipalities most exposed to the virus was lifted just before the election. ${ }^{31}$

In Burundi, amid concerns raised by medical authorities, political rallies amassed large crowds and elections were held, while the government played down the full extent of infection in the country. ${ }^{32}$ A similar approach can be discerned in Tanzania, where President John Magufuli dismissed health experts and discouraged the wearing of face masks ahead of elections in early October. ${ }^{33}$ In Guinea, less than a month after contested parliamentary elections and a referendum on extending the limit of the presidential term, infections grew to 579 including five deaths, when only two cases had been

28 L Masina "Malawi politicians ignore COVID-19 measures for elections" (19 May 2020) Voice of America, available at: <https://www.voanews.com/africa/malawi-politicians-ignorecovid-19-measures-elections> (last accessed 23 August 2021).

29 "Malawi's election cheer dampened by coronavirus surge" (4 July 2020) Reuters, available at: <https://www.reuters.com/article/us-health-coronavirus-malawi/malawis-electioncheer-dampened-by-coronavirus-surge-idUSKBN2450LO> (last accessed 23 August 2021).

30 J Anani “Campagne au Bénin: L’ordre des médecins dénonce le non-respect des mesures sanitaires” [Campaign in Benin: The medical profession denounces lack of respect for hygiene measures] (14 May 2020) La Nouvelle Tribune, available at: <https://lanouvell etribune.info/2020/05/campagne-au-benin-lordre-des-medecins-denonce-le-non-respectdes-mesures-sanitaires/> (last accessed 23 August 2021).

31 EA Abatan and M Matongbada "Benin's local elections further reduce the political space" (27 May 2020, Institute for Security Studies), available at: <https://issafrica.org/isstoday/benins-local-elections-further-reduce-the-political-space> (last accessed 23 August 2021).

32 Republic of Burundi government communiqué (25 March 2020), available at: <https:// www.presidence.gov.bi/wp-content/uploads/2020/03/Coronavirus-communiqu\%C3\% A9.pdf> (last accessed 23 August 2021). Notably, the government warned against any attempt to contradict the level of infection or the need to take preventive measures. See also D Finnan "Political violence and COVID-19 cast shadow over Burundi polls" (18 May 2020) rFi, available at: <https://www.rfi.fr/en/africa/20200518-politicalviolence-and-covid-19-cast-shadow-over-burundi-polls> (last accessed 23 August 2021).

33 "Tanzania president downplays COVID-19 ahead of elections" (19 June 2020) Africa Briefing, available at: <https://africabriefing.org/2020/06/tanzania-president-downplayscovid-19-ahead-of-elections/> (last accessed 23 August 2021). 
registered just before election day. ${ }^{34}$ Moreover, while election management bodies issued guidelines to sensitize voters about the safe conduct of electoral activities and assured the population of the deployment of precautionary measures on polling day, barrier and hygiene procedures were not rigorously and systematically applied in polling stations, notably in Mali. ${ }^{35}$ The dearth of mass testing and data availability in Africa and the downplaying of the pandemic, however, meant that the exact impact or causality of the conduct of electoral activities on the number and rate of infections could not be measured. ${ }^{36}$

\section{Political participation}

In countries where elections were held, the authorities exploited the distraction provided by the global health emergency and the absence of observers to invigorate political repression and limit candidacies. Opposition parties in Benin were barred from local elections in March on the basis of criteria set in a new electoral statute for fielding candidates. Sebastien Ajavon, a political opponent, sought to challenge the Social Liberal Union Party's exclusion from the elections at the African Court. After the court ordered the authorities to postpone elections until it had delivered a decision on the complaint, the government withdrew access to the African Court for individuals and nongovernmental organizations and went ahead to hold the elections. ${ }^{37}$ In the run-up to elections in Burundi, several attacks were reported across the country, including in the Kamenge district of Bujumbura, a stronghold of the ruling party. The party's youth wing, Imbonerakure, abducted and killed Richard Havyarimana, the leader of the opposition CNL party branch in Mwaro province and conducted a number of attacks on CNL party supporters. ${ }^{38}$ In some instances, notably in Benin and Cameroon, as a result of governments dismissing calls for the postponement of elections, opposition parties boycotted elections and called for their supporters to do likewise. Emergency provisions such as lockdowns also weakened opposition forces, including minority

34 MA Simiyu "Digital solutions for African elections in the time of COVID-19" (22 April 2020) AfricLaw, available at: <https://africlaw.com/2020/04/22/digital-solutions-forafrican-elections-in-the-time-of-covid-19/> (last accessed 23 August 2021).

35 I Mules "Mali: Legislative elections hampered by low voter turnout" (30 March 2020) Deutsche Welle, available at: <https:/www.dw.com/en/mali-legislative-electionshampered-by-low-voter-turnout/a-52958735> (last accessed 23 August 2021).

36 See for instance the case of Tanzania: R Chakamba "In Tanzania election, COVID-19 denialism an 'excuse to clamp down' on dissent" (6 November 2020) Devex, available at: <https://www.devex.com/news/in-tanzania-election-covid-19-denialism-an-excuse-toclamp-down-on-dissent-98418> (last accessed 23 August 2021).

37 "Benin: Withdrawal of individuals' right to refer cases to the African Court a dangerous setback in the protection of human rights" (24 April 2020, Amnesty International), available at: <https://www.amnesty.org/en/latest/news/2020/04/benin-le-retrait-auxindividus-du-droit-de-saisir-la-cour-africaine-est-un-recul-dangereux/> (last accessed 23 August 2021).

38 Finnan "Political violence and COVID-19", above at note 32. 
political parties as they were unable to organize public rallies. In Zambia, where presidential elections were expected the following year, the Electoral Commission increased the nomination fees for presidential and parliamentary candidates. ${ }^{39}$

Elections also saw the exacerbation of voter intimidation and suppression. Elections in Burundi and Mali were marred by reports of violence against voters. Additionally, in some countries, the authorities introduced particularly stringent voter registration processes. In Côte d'Ivoire, the first COVID-19 testing site was set up in Yopougon, an opposition-friendly suburb of Abidjan, inciting protests against exposure to the disease and political scheming. Simultaneously, the issuance of new national identity cards began, with arbitrary restriction measures in enrolment centres, conditions that protesters perceived as moves towards voter suppression. ${ }^{40}$ In Uganda, where presidential elections were scheduled for early 2021, voter registration closed as early as December 2019, disenfranchising over two million first-time voters, while the National Electoral Commission referred to a lack of resources and time to register new voters. ${ }^{41}$ Moreover, in general, safety measures were reported to be rare at polling stations. Alternative voting arrangements for the elderly and immunocompromised individuals were not provided. This could potentially have deterred a number of voters from exercising their vote in elections, reflected in lower voter turnout across the elections held during the pandemic.

\section{Civil unrest}

Indefinite postponements and decisions to adjourn elections without adequate consultation are prone to foster unrest and escalate existing strife. In Ethiopia, where elections were postponed indefinitely until timelines were drawn at the very end of the year, the ruling party refused the call by opposition representatives to form a caretaker government upon the expiry of the term of the Assembly. Simmering ethnic tensions flared up, with recurrent brutal attacks and clashes with government forces in the Oromia, Tigray and Benishangul-Gumuz regions. The political crisis caused by Tigray holding elections despite the government's postponement resulted in many deaths, the arrest of opposition leaders and protesters, the displacement of large

39 "Surge in nomination fees for Zambia's 2021 general elections receive mixed reactions" (20 June 2020) CGTN, available at: <https://africa.cgtn.com/2020/06/20/surge-in-no mination-fees-for-zambias-2021-general-elections-receive-mixed-reactions/> (last accessed 23 August 2021).

40 "Politics and COVID-19 clash in Côte d'Ivoire" (26 May 2020, National Democratic Institute), available at: <https://www.ndi.org/our-stories/politics-and-covid-19-clash-c-ted-ivoire> (last accessed 23 August 2021).

41 M Kujeke "Uganda stifles the youth vote a year ahead of elections" (31 March 2020, Institute for Security Studies), available at: <https://issafrica.org/iss-today/uganda-stiflesthe-youth-vote-a-year-ahead-of-elections> (last accessed 23 August 2021). 
numbers of the local population and severe humanitarian concerns. ${ }^{42}$ In the same vein, in Mali, frustrations over disputed parliamentary elections in March and April deepened the legitimacy crisis caused by the Constitutional Court overturning some of the provisional poll results, handing around 30 seats to the ruling party, ${ }^{43}$ which ignited violent protests. After President Ibrahim Boubacar Keita rejected calls by the opposition for his resignation and the conclusion by an Economic Community of West African States (ECOWAS) mission that the results should be reviewed and fresh elections held, ${ }^{44}$ deadly protests dawned in Bamako in June. Protesters blocked bridges, attacked the Parliament building and forced the national broadcaster ORTM off air. ${ }^{45}$ In Côte d'Ivoire, elections went ahead, despite opposition calls for their postponement, amid reports of attacks, notably in Yamoussoukro, and protests in Abidjan. ${ }^{46}$

\section{Civic space}

Responses to electoral programming were accompanied by new waves of restrictions on civic space, ${ }^{47}$ hampering public debate, mobilization, oversight and accountability of state institutions in the lead-up to the polls. A series of severe retaliatory incidents included targeted physical attacks and the incarceration of human rights defenders, members of civil society organizations and members of Parliament (MPs). ${ }^{48}$ In Egypt, where parliamentary elections were scheduled for November, activists and journalists were jailed on trumped-up charges of misusing social media or inciting terrorism. Mohamed Morsi, Awny Nafae, Nora Younis and Sanaa Seif were among

42 "Tigray crisis: Ethiopia region at risk of huge 'humanitarian disaster'" (2 February 2021) BBC, available at: <https://www.bbc.com/news/world-africa-55905108> (last accessed 23 August 2021).

43 Decree No 2020-04/CC-EL of 30 April 2020 on the Declaration of the Final Results of the Second Round of the Election of Deputies to the National Assembly (ballot of 19 April 2020) Constitutional Court, Republic of Mali.

44 "West African neighbors seek to mediate in Mali crisis" (15 July 2020) Voice of America, available at: <https://www.voanews.com/africa/west-african-neighbors-seek-mediatemali-crisis> (last accessed 23 August 2021).

45 "Mali protest leader calls for calm after demonstrations turn deadly" (13 July 2020) france 24, available at: <https://www.france24.com/en/20200712-mali-protest-leader-calls-forcalm-after-demonstrations-turn-deadly> (last accessed 23 August 2021).

46 "Côte d'Ivoire: Post-election violence, repression" (2 December 2020, Human Rights Watch), available at: <https://www.hrw.org/news/2020/12/02/cote-divoire-post-electio n-violence-repression> (last accessed 23 August 2021).

47 "Press release of the special rapporteur on human rights defenders and focal point on reprisals in Africa on the protection of human rights defenders during the COVID-19 pandemic" (1 May 2020, African Commission on Human and Peoples' Rights), available at: <https://www.achpr.org/pressrelease/detail?id=496> (last accessed 23 August 2021).

48 LA Bagnetto "Press freedom violations throughout Africa linked to COVID-19 coverage" (14 April 2020) rFi, available at: <https://www.rfi.fr/en/africa/20200414-press-freedomviolations-throughout-african-continent-linked-to-covid-19-coverage> (last accessed 23 August 2021). 
more than 16 journalists to be arrested after criticising the government's handling of the pandemic. ${ }^{49}$ The Egyptian Council for Media Regulation also threatened to impose sanctions against media coverage of the pandemic. ${ }^{50}$ The authorities arrested novelist Ahdaf Soueif and Professor of Political Science Rabab El- Mahdi, after they staged protests calling for the release of prisoners over concerns of rapid transmission of the virus in detention. ${ }^{51}$

In Zimbabwe, three political leaders from the opposition party Movement for Democratic Change Alliance, including MP Joana Ruvimbo Mamombe, were abducted, tortured and sexually abused after having participated in a flash protest against rising levels of hunger and abuse of governmentsourced food aid during lockdown. ${ }^{52}$ Opposition officials, notably Regai Tsunga, MP for Mutasa South, were also arrested and fined for donating food relief to vulnerable groups in their constituencies. ${ }^{53}$ In some countries, governments used the decline in checks and balances to hasten the enactment of repressive legislation. In Tanzania for instance, Parliament amended the Basic Rights and Duties Enforcement Act to limit the criteria for legal standing to challenge a law or policy violating the Constitution's Bill of Rights. ${ }^{54}$

\section{Access to information}

As electoral campaigns and civic awareness and sensitization moved online during the pandemic, those without internet access were adversely affected. The pandemic also saw a general surge in misinformation and disinformation. Fake electoral announcements were particularly prone to mislead populations in the tense political climate in many African countries. In Niger, for instance,

49 T Allinson and L Sanders IV "Egypt targets activists in new wave of arrests" (26 June 2020) Deutsche Welle, available at: <https://www.dw.com/en/egypt-targets-activists-in-newwave-of-arrests/a-53952214> (last accessed 23 August 2021).

50 "Egypt bans media covering of Sinai, Renaissance Dam, Libya and coronavirus" (19 June 2020) Middle East Observer, available at: <https://www.middleeastobserver.org/ 2020/06/19/egypt-bans-media-covering-of-sinai-renaissance-dam-libya-and-coronavirus/> (last accessed 23 August 2021).

51 E Graham-Harrison "Egypt arrests activists including Ahdaf Soueif over coronavirus protest” (18 March 2020) The Guardian, available at: <https://www.theguardian.com/world/ 2020/mar/18/egypt-arrests-activists-calling-prisoners-release-coronavirus-ahdaf-soueif> (last accessed 23 August 2021).

52 “Zimbabwe's MDC 'abductees arrested for lying about torture”' (11 June 2020) BBC News, available at: <https://www.bbc.com/news/world-africa-53005447> (last accessed 23 August 2021).

53 "MDC Mutasa South MP arrested for donating mealie-meal" (22 April 2020) New Zimbabwe, available at: <https://www.newzimbabwe.com/mdc-mutasa-south-mp-arres ted-for-donating-mealie-meal/> (last accessed 23 August 2021).

54 O Nyeko "Public interest litigation under threat in Tanzania" (18 June 2020, Human Rights Watch), available at: <https:/www.hrw.org/news/2020/06/18/public-interestlitigation-under-threat-tanzania> (last accessed 23 August 2021). 
a fake social media announcement, attributed to the Electoral Commission, declared the suspension of biometric voter registration. ${ }^{55}$ Furthermore, many countries enforced restrictions on traditional media, including shutting down newspaper outlets and television and radio stations, and impeding access to information from the frontline on elections and the health crisis. In a highly charged atmosphere, made worse by the indefinite postponement of elections, Ethiopia experienced prolonged periods of internet shutdowns after civil unrest caused by the killing of Oromo musician and antigovernment activist Hachalu Hundessa. ${ }^{56}$ In Zimbabwe, the police commissioner exempted only those from broadcasting services (which are usually government controlled) from the lockdown, claiming that journalists were not essential workers. ${ }^{57}$ Journalist Hopewell Chin'ono, known to have reported corruption in the procurement of COVID-19 supplies, was abducted and detained by government authorities. ${ }^{58}$ In Zambia, where general elections were set for August 2021, the licence of independent television station Prime Television was revoked under the guise of protecting the public interest and public safety. ${ }^{59}$ In some countries, internet access or access to social media and messaging apps was cut off on polling day. In Burundi, access to social media platforms was intercepted intermittently throughout election day. ${ }^{60}$ Similarly, access to messaging services was blocked in Togo ${ }^{61}$ and disruptions to broadband and the telephone network in Guinea preceded a

55 The National Electoral Commission responded to the incident. See communiqué of 22 March 2020 (in French), available at: <http://www.ceniniger.org/wp-content/uploads/ 2020/03/DEMENTI-DE-LA-CENI.pdf> (last accessed 23 August 2021).

56 "Ethiopia enters 3rd week of internet shutdown after deadly unrest" (14 July 2020) CBC, available at: <https://www.cbc.ca/news/world/ethiopia-internet-shutdown-unrest-1. 5649893> (last accessed 23 August 2021).

57 "SADC: Restrictive COVID-19 regulations presenting concerning ramifications for enjoyment of human rights, including livelihoods" (27 May 2020, open letter from Amnesty International, Freedom House, Southern Africa Litigation Centre and Southern Africa Human Rights Defenders Network), available at: <https:/freedomhouse.org/article/ sadc-restrictive-covid-19-regulations-presenting-concerning-ramifications-enjoymenthuman> (last accessed 23 August 2021).

$58 \mathrm{~J}$ Burke "Prominent Zimbabwe journalist detained in latest abduction of government critics" (20 July 2020) The Guardian, available at: <https://www.theguardian.com/world/ 2020/jul/20/prominent-zimbabwe-journalist-detained-in-latest-abduction-of-governmentcritics> (last accessed 23 August 2021).

59 S Sishuwa "Lungu's strategic march to 2021: The shutdown of Prime TV" (11 April 2020) News Diggers, available at: <https://diggers.news/lifestyle/2020/04/11/lungus-strategicmarch-to-2021-the-shutdown-of-prime-tv/> (last accessed 23 August 2021).

60 F Anthonio and B Taye "\#KeepItOn: Burundi silences the majority on election day" (20 May 2020) Access Now, available at: <https://www.accessnow.org/keepiton-burundi-sil ences-the-majority-on-election-day/> (last accessed 23 August 2021).

61 F Anthonio “A shutdown taints Togo's 2020 presidential elections: What happened and what's next” (2 March 2020) Access Now, available at: <https://www.accessnow.org/ashutdown-taints-togos-2020-presidential-elections-what-happened-and-whats-next/> (last accessed 23 August 2021). 
complete internet shutdown with no explanation from the government authorities. ${ }^{62}$

\section{THE NORMATIVE AND INSTITUTIONAL FRAMEWORK OF ELECTORAL GOVERNANCE IN AFRICA}

Over the last two decades, the regulation and institutionalization of electoral management have advanced markedly across African countries. Elections are increasingly conducted within an extensive plethora of rules, procedures and mechanisms. ${ }^{63}$ Similarly, at the regional level, the emergence of new policy frameworks and structures focused on good governance and democratization have reflected the ambitions of democratic consolidation on the continent. ${ }^{64}$ The pandemic underscored the need for further interrogation of electoral norms and standards in view of nascent challenges introduced to the electoral cycle by new infectious disease outbreaks. First, what is the scope of state duties in safeguarding health in the conduct of elections? Secondly, how can extant international electoral obligations be refined to respond to accessibility concerns of high-risk and vulnerable voters, such that elections are inclusive and participative? Finally, what are the legal conditions and limitations regarding the postponement of elections? The first part of this section presents the electoral norms and standards guiding the conduct of democratic elections, examining the notions of safety, inclusiveness and timeliness. It then provides an overview of the regional electoral governance architecture, underlining relevant actors playing an important role in steering the development of rules and safeguards necessary to mitigate the effects of the pandemic on the electoral process.

\section{Normative framework}

The body of rules and practice on the conduct of elections proliferated after the end of the Cold War in the face of growing concern for democratic governance, a thriving interest in doctrinal and methodological appraisals of democracy and electoral processes, and the increasing prevalence of election

62 F Anthonio and B Taye "A broken promise to \#KeepItOn: Guinea cuts internet access and blocks social media on referendum day" (24 March 2020) Access Now, available at: $<$ https://www.accessnow.org/a-broken-promise-to-keepiton-guinea-cuts-internet-accessand-blocks-social-media-on-referendum-day/> (last accessed 23 August 2021).

63 For an early review, see S Mozaffar "Patterns of electoral governance in Africa's emerging democracies" (2002) 23/1 International Political Science Review 85.

64 See, among others: Lomé Declaration of July 2000 on the Framework for an OAU Response to Unconstitutional Changes of Government, AHG/Decl.5 (XXXVI); New Partnership for Africa's Development (adopted July 2001); and African Charter on Democracy, Elections and Governance (2007). See also CC Aniekwe and SM Atuobi "Two decades of election observation by the African Union: A review" (2016) 15/1 Journal of African Elections 25. 
observation. ${ }^{65}$ An intricate corpus of international norms and standards now inform the assessment of elections, drawn from public international law, election observation practices by international organizations and the jurisprudence of regional courts. ${ }^{66}$ International election observation rests on human rights instruments, which enshrine the right to political participation, notably the right to vote and participate in elections. ${ }^{67}$ The underpinning determinants of credible observation were only relatively recently codified in the Declaration of Principles for International Election Observation and the Code of Conduct for International Election Observers. ${ }^{68}$

The electoral process is characterized by a number of qualities.

\section{Free and fair}

The obligation for states to conduct periodic and genuine elections is enshrined in international law. The Universal Declaration of Human Rights affirms: "[t]he will of the people shall be the basis of the authority of government; this will shall be expressed in periodic and genuine elections which shall be by universal and equal suffrage and shall be held by secret vote or by equivalent free voting procedures". 69 Similarly, the International Covenant on Civil and Political Rights (ICCPR) prescribes: "[e]very citizen shall have the right and the opportunity, without any of the distinctions mentioned in article 2 and without unreasonable restrictions: ... (b) To vote and to be elected at genuine periodic elections which shall be by universal and equal suffrage and shall be held by secret ballot, guaranteeing the free expression of the will of the voters". ${ }^{70}$

65 WM Reisman "International election observation" (1992) 4/1 Pace International Law Review 1; A Davis-Roberts and DJ Carroll "Using international law to assess elections" (2010) 17/3 Democratization 416.

66 See "Enhancing the effectiveness of the principle of periodic and genuine elections: Framework for future efforts" UN Commission on Human Rights res 1989/51 (7 March 1989) annex, UN doc E/1989/20, chap II, sec A; Copenhagen Document of the Conference on the Human Dimension of the CSCE (1990); UN res "Enhancing the effectiveness of the principle of periodic and genuine elections" (report of the secretary general, 8 November 1995), doc A/50/736; Inter-Parliamentary Union Declaration on Criteria for Free and Fair Elections (unanimously adopted at the Inter-Parliamentary Council's 154th session, Paris, 26 March 1994); Venice Commission Code of Good Practice in Electoral Matters (adopted at the Venice Commission's 51st and 52nd sessions, 5-6 July and 18-19 October 2002); The Carter Centre Election Obligations and Standards Manual (2009); The Carter Centre Election Observations and Standards database (launched in 2010); and the Election Observation and Democratic Support eLex International Election-Related Case Law Database.

67 See Reisman "International election observation", above at note 65.

68 The Declaration of Principles for International Election Observation and the Code of Conduct for International Election Observers was developed at the initiative of the National Democratic Institute and the UN Electoral Assistance Division; it was commemorated at the UN on 27 October 2005 and is endorsed by 55 intergovernmental and international organizations.

69 Universal Declaration of Human Rights (adopted 10 December 1948), UN GA res 217A (III), art 21(3).

70 ICCPR (1976) (entered into force 23 March 1976) 999 UN Treaty Series 171, art 25. 
The obligation is also entrenched in regional instruments. ${ }^{71}$ Pertinently, the African Charter on Democracy, Elections and Governance (ACDEG) states: "[s]tate Parties re-affirm their commitment to regularly holding transparent, free and fair elections in accordance with the Union's Declaration on the Principles Governing Democratic Elections in Africa". ${ }^{72}$ The African Union (AU) Declaration on the Principles Governing Democratic Elections in Africa also stipulates:

"Democratic elections should be conducted:

(a) freely and fairly;

(b) under democratic constitutions and in compliance with supportive legal instruments;

(c) under a system of separation of powers that ensures in particular, the independence of the judiciary;

(d) at regular intervals, as provided for in National Constitutions;

(e) by impartial, all-inclusive competent accountable electoral institutions staffed by well-trained personnel and equipped with adequate logistics". ${ }^{73}$

The precept of democratic elections is concomitant with the fulfilment of a range of other obligations, including universal and equal suffrage, secrecy of the ballot, the right to participate in public affairs, the right to vote, the right to be elected, freedom of assembly, freedom of movement, freedom from discrimination, equal access to public service, freedom of expression, access to information, right to security of the person, right to an effective remedy, right to a fair hearing, the prevention of corruption and adherence to the rule of law. ${ }^{74}$

Notably, the African Charter on Human and Peoples' Rights (African Charter) enshrines the right to participation in political and public life: "[e]very citizen shall have the right to participate freely in the government of his country, either directly or through freely chosen representatives in accordance with the provisions of the law". ${ }^{75}$ The Protocol to the African

71 See American Convention on Human Rights (1969) (entered into force 18 July 1978) 1144 UN Treaty Series 143 at 145, art 25; Inter-American Democratic Charter (2001) adopted at the fourth plenary session, 5 June 2001, AG/RES. 1838 (XXXI-O/01); First Protocol to the European Convention for the Protection of Human Rights and Fundamental Freedoms (1952) (entered into force 18 May 1954) 213 UN Treaty Series 262, art 3; Charter of Fundamental Rights of the European Union (2000) Official Journal of the European Communities C 364/1 (19 December 2000), art 39.

72 ACDEG (2007) (entered into force 15 February 2012), art 17; see also id, art 3.

73 AU Declaration on the Principles Governing Democratic Elections in Africa (2002) AHG/Decl.1 (XXXVIII), art 4.

74 UN Human Rights Committee General Comment No 25: Article 25 (Participation in Public Affairs and the Right to Vote, The Right to Participate in Public Affairs, Voting Rights and the Right of Equal Access to Public Service) (12 July 1996) CCPR/ C/21/Rev.1/Add.7, paras 9-22.

75 African Charter (Banjul Charter) (entered into force 21 October 1986) CAB/LEG/67/3 rev 5 , (1982) 21 International Legal Materials 58, art 13(1). 
Charter on Human and Peoples' Rights on the Rights of Older Persons in Africa underlines that state parties shall: "[e]nact legislation and take other measures that protect the right of Older Persons to express opinions and participate in social and political life". ${ }^{76}$

Periodic and genuine character are the core tenets of democratic elections, common to all iterations of international electoral obligations. "Periodic" elections refers to frequency and the notion of regular or reasonable intervals. While not defined, "genuine" elections has been interpreted to invoke compliance with international electoral obligations ${ }^{77}$ and the offer of a real and informed choice. ${ }^{78}$ The concept of "free and fair" elections emerged later, along with the development of the body of standards and norms underpinning elections. While initially obscure, this concept has been defined as the over-arching doctrine of the electoral cycle, marrying "transparency", "integrity" and "credibility", overlapping obligations of result and conduct, and including a comprehensive list of factors. ${ }^{79}$ The constituents of "free" elections include the ability to exercise one's franchise in secrecy without restrictions or repercussions, as well as an enabling political environment and legal framework where fundamental rights and freedoms are fulfilled and protected. ${ }^{80}$ "Fair" elections alludes primarily to conformity with electoral procedures, notably management by an impartial electoral management body, equitable access to voter information, and financial resources for all political parties and independent candidates. ${ }^{81}$ The "peaceful" quality of elections, referring to the provision of a secure and stable environment for voting, has also more recently been recognized as an integral yardstick of democratic elections. ${ }^{82}$

76 Protocol to the African Charter on Human and Peoples' Rights on the Rights of Older Persons in Africa (adopted 31 January 2016 by the AU Assembly at the second AU summit, Maputo, Mozambique), art 5(3).

77 "International obligations for elections: Guidelines for legal frameworks" (2014, International Institute for Democracy and Electoral Assistance), available at: <https:// www.idea.int/sites/default/files/publications/international-obligations-for-elections.pdf> at 37 (last accessed 23 August 2021).

78 Davis-Roberts and Carroll "Using international law", above at note 65 at 423.

79 See notably, GS Goodwin-Gill Free and Fair Elections: International Law and Practice (1994, Inter Parliamentary Union); J Elklit and P Svensson "What makes elections free and fair?" (1997) 8/3 Journal of Democracy 32; MD Boda "Judging elections by public international law: A tentative framework" (2005) 41/3 Representation 208; and "Overview of state obligations relevant to democratic governance and democratic elections" (Democracy Reporting International and the Carter Centre policy paper), available at: <http://aceproject.org/ero-en/misc/overview-of-state-obligations-relevant-to> (last accessed 23 August 2021).

80 See for instance Southern African Development Community Principles and Guidelines Governing Democratic Elections, adopted 20 July 2015 by the Ministerial Committee of the Organ on Politics, Defence and Security Cooperation, Pretoria, Republic of South Africa at iii (Definitions).

81 Ibid.

82 Ibid. 
Safe

The control of epidemic diseases is expressly enumerated as an illustrative element of state obligations under the right to health:

"1. The States Parties to the present Covenant recognize the right of everyone to the enjoyment of the highest attainable standard of physical and mental health.

2. The steps to be taken by the States Parties to the present Covenant to achieve the full realization of this right shall include those necessary for: ...

(c) The prevention, treatment and control of epidemic, endemic, occupational and other diseases". ${ }^{83}$

State duties of safety vis-à-vis polling station workers and electoral officials can be discerned under the right to safe and healthy working conditions. ${ }^{84}$ As for the safety of the electorate and political candidates, the relationship between the right to health and freedoms of association, assembly, movement and access to information is formally recognized. ${ }^{85}$ The nexus between the right to health and other electoral rights is, however, more difficult to establish. International electoral norms and standards include the right to security of the person, which is construed to extend to all stakeholders in the electoral process; in the electoral context, this involves protecting the physical and mental state of the person $^{86}$ and freedom from injury. ${ }^{87}$ Yet the safeguard is geared more to the prevention of undue coercion or intimidation, likely to distort the free expression of the voter's will ${ }^{88}$ and, as such, does not currently envisage health considerations.

The safe conduct of elections during a pandemic requires mainstreaming a public health perspective in the electoral cycle. In terms of electoral programming, the state should be guided by a number of factors when holding or re-scheduling elections, including the spread of the disease, the case growth trajectory and the capacity of the country's healthcare system. ${ }^{89}$ Throughout

83 International Covenant on Economic, Social and Cultural Rights (entered into force 3 January 1976) 993 UN Treaty Series 3, art 12.

84 Id, art 7.

85 Committee on Economic Social and Cultural Rights General Comment No 4: The Right to the Highest Attainable Standard of Health (Article 12) (adopted at its 22nd session, 11 August 2000), UN doc E/C.12/2000/4, para 3.

86 Davis-Roberts and Carroll "Using international law", above at note 65 at 428.

87 "International obligations for elections", above at note 77 at 47.

88 See also in this context, obligations to protect the safety of women voters and candidates: "Guidelines for states on the effective implementation of the right to participate in public affairs" (2018, Office of the UN High Commissioner for Human Rights), available at: <https://www.ohchr.org/EN/Issues/Pages/DraftGuidelinesRighttoParticipationPublicAffairs. aspx> (last accessed 23 August 2021).

89 "Safeguarding health and elections" (May 2020, International Foundation for Electoral Systems), available at: <https://www.ifes.org/sites/default/files/ifes_covid19_briefing_ series_safeguarding_health_and_elections_may_2020.pdf> (last accessed 23 August 2021). 
the electoral process, states need to ensure a secure environment. This includes sensitizing the population and political candidates to the disease, means of transmission, hygiene practices and preventive measures. ${ }^{90}$ States need to consider promoting campaigns using only online, digital and traditional media (television and radio), as well as the authorities' duty of neutrality in respect of media campaign activities. ${ }^{91}$ On election day, states need to ensure the provision of face masks, gloves, hand-washing facilities and sanitizer for all voters, and personal protective equipment for poll workers. Polling stations need to have temperature control points, disinfect surfaces and voting equipment at regular intervals, and provide demarcated spacing and physical barriers for queues. States also need to consider increasing the number of polling stations, scheduling voting or staggering polling across a longer period. ${ }^{92}$ States also need to examine the feasibility of automating electoral procedures to reduce the number of polling station workers.

\section{Inclusive}

The right to equal participation in political and public life is embedded in international human rights law. ${ }^{93}$ Notably, the AU Declaration on the Principles Governing Democratic Elections in Africa states: “[e]very citizen has the right to fully participate in the electoral processes of the country, including the right to vote or be voted for, according to the laws of the country and as guaranteed by the Constitution, without any kind of discrimination". ${ }^{94}$

Significantly, international law prohibits both formal (de jure) and substantive (de facto) discrimination. Discrimination is defined as: "distinction, exclusion, restriction or preference which is based on any ground such as race, colour, sex, language, religion, political or other opinion, national or social origin, property, birth or other status, and which has the purpose or effect of nullifying or impairing the recognition, enjoyment or exercise by all persons, on an equal footing, of all rights and freedoms". ${ }^{95}$

90 "Key public health considerations / recommendations for countries conducting elections in the context of COVID-19" (May 2020, WHO Regional Office for Africa), available at: <https://www.afro.who.int/sites/default/files/Covid-19/Techinical\%20documents/Key\% 20Public\%20Health\%20Considerations-Recommendations $\% 20$ for $\% 20$ Countries \% 20conducting\%20elections.pdf> (last accessed 11 September 2021).

91 This is already recognized in treaties; see for instance ACDEG, art 17(3).

92 "Respect for democracy, human rights and the rule of law during states of emergency: Reflections" (26 May 2020, European Commission for Democracy Through Law (Venice Commission)) CDL-PI (2020)005rev.

93 ICCPR, art 25; International Convention on the Elimination of All Forms of Racial Discrimination (1965) (entered into force 4 January 1969) 660 UN Treaty Series 195, art 5; International Convention on the Elimination of All Forms of Discrimination against Women (1979) (entered into force 3 September 1981) 1249 UN Treaty Series 13, art 7; Convention on the Rights of Persons with Disabilities (entered into force 3 May 2008) A/RES/61/106, annex 1, art 29; General Comment No 25, above at note 74, para 10.

94 AU Declaration on the Principles Governing Democratic Elections in Africa, art IV(2).

95 UN Human Rights Committee General Comment No 18: Non-Discrimination (adopted at the 37th session of the Human Rights Committee, 10 November 1989), para 7. 
The pandemic calls for increased attention to accessibility for the elderly, individuals with underlying chronic health conditions at a higher risk of contracting the disease and other vulnerable or marginalized groups. The relationship between age, ethnicity, socio-economic status and mortality is well documented in the context of infectious disease outbreaks, and has been echoed more recently in similar studies in respect of COVID-19. ${ }^{96}$ In addition, the nexus between socio-economic status and political rights was also underlined in early interpretations of the implementation of political rights. ${ }^{97}$ Barriers to equal participation in political and public life are increasingly construed expansively. ${ }^{98}$ In light of the vulnerability of some groups and the quarantine or hospitalization of infected voters due to illness or sanitary protocols, there should be a positive obligation on states to deploy alternative voting arrangements, such as proxy voting, mail-in ballots or other remote voting mechanisms to prevent disenfranchisement. In this regard, international law also presupposes integration with national policies and laws, ensuring equal participation of individuals and groups, the use of temporary special measures and new modalities of participation, including information and communications technology. ${ }^{99}$

\section{Timely}

The postponement of elections (the interruption of periodic elections) in emergencies is envisaged in international law but is not subject to a welldefined regime of safeguards. Emergencies permit derogation from electoral rights. ${ }^{100}$ However, derogation from obligations needs to be justified on the basis of the prevalence of a public emergency "threatening the life of the nation" and needs to be "exceptional, proportionate and temporary". ${ }^{101}$ Specifically, the postponement of elections must meet a necessity and proportionality test without undermining democracy:

96 See, for instance: L Platt and R Warwick "Are some ethnic groups more vulnerable to COVID-19 than others" (May 2020, The Institute for Fiscal Studies), available at: <https:// ifs.org.uk/inequality/chapter/are-some-ethnic-groups-more-vulnerable-to-covid-19-thanothers / (last accessed 2 October 2021).

97 "Study of discrimination in the matter of political rights" (UN Sub-Commission on Prevention of Discrimination and Protection of Minorities, annex to res I (XIV), 14th session, 1962), UN doc E/CN.4/Sub.2/213/Rev.1.

98 "Factors that impede equal political participation and steps to overcome these challenges" (30 June 2014, Office of the UN High Commissioner for Human Rights), UN doc A/HRC/27/29, para 45.

99 "Guidelines for states on the effective implementation", above at note 88, paras 39 and 61.

100 Electoral rights are not included among the non-derogable rights: ICCPR, art 4(2).

101 UN Human Rights Committee General Comment No 29: Article 4: Derogations During a State of Emergency (31 August 2001) CCPR/C/21/Rev.1/Add.11; UN Commission on Human Rights "The Siracusa Principles on the Limitation and Derogation Provisions in the International Covenant on Civil and Political Rights" (28 September 1984) E/CN.4/1985/4. See also "Statement on derogations from the covenant in connection with the COVID-19 pandemic" (24 April 2020, UN Human Rights Committee), UN doc CCPR/C/128/2. 
"Postponement of scheduled elections necessitated by public emergency may be permitted in certain limited circumstances, but only if and to the extent strictly required by the exigencies of the situation. Any such extraordinary measures must comply with all the rigid international standards for such derogations and must not threaten democracy itself. Indeed, the Universal Declaration itself proclaims that any limitations on the rights and freedoms contained therein must be for the purpose of 'meeting the just requirements of morality, public order and the general welfare in a democratic society' (art 29, para 2). Accordingly, the interruption of periodicity will, in all but the most exceptional circumstances, violate international standards." ${ }^{102}$

Proportionality is a general principle of international law, comprising a balancing act between conflicting interests. It includes an examination of three subprinciples. Any limitation or restriction of the human rights obligation needs to be suitable for achieving the legitimate aim (adequacy) and constitute the least intrusive means among those similarly effective (necessity), and the advantages for the interest to be protected should outweigh the disadvantages or costs (proportionality, in the strict sense). ${ }^{103}$ The emphasis on democracy in the context of electoral rights seems to add an additional requirement within the proportionality test in light of the potential for an erosion of the principle, since elections determine the legitimacy and accountability of political power. As a result, measures against abuse need to be made available, including judicial control by an impartial court, consultations with political parties before any postponement, a statutory time limit to the postponement ${ }^{104}$ and parliamentary approbation by a qualified majority. ${ }^{105}$ A number of considerations will inform the proportionality of postponement in light of the epidemic trajectory in the state, notably the timing of the epidemic within the overall electoral timeframe, campaigning options and costs already incurred, safety of election management staff, voting modalities and alternative voting arrangements, online observation facilities and financial constraints.

\section{Institutional framework}

The Democracy and Elections Assistance Unit

The Democracy and Elections Assistance Unit (DEAU) was established within the Department of Political Affairs of the AU Commission in June 2006 with

102 Human Rights and Elections: A Handbook on the Legal, Technical and Human Rights Aspects of Elections (1994, UN Centre for Human Rights), paras 72 and 73, available at: <https://www. ohchr.org/Documents/Publications/training2en.pdf> (last accessed 23 August 2021).

103 UN Human Rights Committee General Comment No 27: Freedom of movement, UN doc CCPR/C/21/Rev.1/Add.9 (1999), para 14.

104 K Ellena "Legal considerations when delaying or adapting elections" (2020, International Foundation for Electoral Systems), available at: <https://www.ifes.org/sites/default/files/ ifes_covid-19_briefing_series_legal_considerations_when_delaying_or_adapting_electio ns_june_2020.pdf> (last accessed 23 August 2021).

105 "Respect for democracy, human rights", above at note 92, para 102. 
a view to operationalising the Declaration on the Principles Governing Democratic Elections in Africa and monitoring the conduct of elections in African states. ${ }^{106}$ It became operational in May 2008. Its mandate focuses on the development of a methodology and mechanisms for monitoring and observing elections, the implementation and coordination of AU electoral observation and monitoring missions, and capacity-building of national electoral institutions of member states. ${ }^{107}$ The Democracy and Elections Assistance Fund provides financial support for DEAU's activities.

By early 2021, DEAU had developed the AU Guidelines on Elections in Africa in the Context of the Novel Coronavirus (COVID-19) Pandemic and Other Public Health Emergencies (AU COVID Election Guidelines). ${ }^{108}$

\section{$A \cup$ electoral observation and monitoring missions}

After the AU's ${ }^{109}$ first involvement in election observation in 1989 in Namibia, where it joined the UN to ensure the fulfilment of UN Security Council resolution 435, it has become increasingly engaged in election observation and monitoring. By 2003, it had acted in over 100 elections in 43 member states. ${ }^{110}$ In 2008, following the Kenyan post-electoral crisis, the AU Political Affairs Department took the administrative decision to observe all national elections, without awaiting a formal invitation. AU electoral observation and monitoring missions include observation, monitoring, mediation, technical assistance, and supervision and audit. ${ }^{111}$ These missions are ordinarily composed of technical experts, an administrative team, leadership teams and a team of

106 Decision on the Establishment and Organization of a Democracy and Electoral Assistance Unit and Fund, AU Executive Council decision 300 (IX), AU doc EX.CL/272 (IX) (25-29 June 2006).

107 African Union Election Observation Manual (2013, AU Commission).

108 There was a significant delay before the AU Commission issued the guidelines. AU Commissioner for Political Affairs Minata Samate Cessouma referred to the imminent development of guidelines in May 2020. See "Ambassador Minata Samate Cessouma presides the virtual meeting of African elections management bodies on COVID-19 and elections in Africa" (AU Commission press release, 29 May 2020), available at: <https://au. int/en/pressreleases/20200529/ambassador-minata-samate-cessouma-meeting-covid-19and-elections-africa> (last accessed 23 August 2021). In its July 2020 study of the governance response to COVID-19, the African Peer Review Mechanism (APRM) highlighted the urgent need for guidelines on the conduct of elections: "Africa's governance response to COVID-19" (24 July 2020, APRM), available at: <https://au.int/en/documents/ 20200724/africas-governance-response-covid-19> (last accessed 23 August 2021). The communiqué of the 976th meeting of the AU Peace and Security Council on AU Guidelines on Elections in Africa in the Context of the Novel Coronavirus (COVID-19) Pandemic and Other Public Health Emergencies (29 January 2021) called for member countries to comment on the guidelines. In addition, the communiqué of the 982nd meeting of the AU Peace and Security Council on the consideration of the report of the chairperson of the Commission on Elections in Africa (25 February 2021) called upon member states to expedite the adoption and implementation of the guidelines.

109 Then the Organization of African Unity.

110 African Union Election Observation Manual, see above at note 107 at 20.

111 Guidelines for AU Electoral Observation and Monitoring Missions (2002), art 4.3. 
observers. They are headed by a head of mission, usually a former president, former head of government or other eminent personality. They draw their mandate from the Guidelines for AU Electoral Observation and Monitoring Missions. ${ }^{112}$

In the course of the first year of the pandemic, the AU mostly undertook virtual missions as travel restrictions had precluded large-scale observer missions. Small observation missions were conducted in Côte d'Ivoire, Guinea and Tanzania. ${ }^{113}$

\section{The AU Peace and Security Council}

The AU Peace and Security Council (PSC) took the decision in 2012 to review the activities of the Political Affairs Department relating to elections on the continent on a regular basis. ${ }^{114}$ Since then, the PSC has issued decisions on elections in Africa. The PSC may institute sanctions whenever an unconstitutional change of government takes place in a member state. ${ }^{115}$ The PSC established the Committee on Sanctions in 2009.116

Decisions to maintain or postpone elections in the face of the pandemic have in most instances led to constitutional tension, civil unrest and an exacerbation of security challenges, as highlighted in the first section of this article. In considering the conduct of elections since the outbreak of the pandemic, ${ }^{117}$ the PSC has highlighted the sovereignty of states in the organization of elections and prompted states to adopt and implement the AU COVID Election Guidelines. ${ }^{118}$

\section{Regional economic communities}

The regional economic communities (RECs) have set up a number of mechanisms relating to democratic governance and elections. The Electoral Commissions Forum of Southern African Development Community (SADC) Countries (ECF-SADC) was launched in 1998 to strengthen cooperation among the electoral commissions of the sub-region and promote conditions for the conduct of credible elections. Its members currently include the electoral management bodies of 16 SADC countries: Angola, Botswana, Comoros, Democratic Republic of the Congo, Eswatini, Lesotho, Madagascar, Malawi,

112 Ibid.

113 L Louw-Vaudran "Election observation in Africa put to the test" (12 November 2020, Institute for Security Studies), available at: <https://issafrica.org/iss-today/electionobservation-in-africa-put-to-the-test> (last accessed 23 August 2021).

114 PSC's 311th meeting Addis Ababa, Ethiopia (press statement, 16 February 2012), PSC/PR/BR.(CCCXI).

115 Protocol Relating to the Establishment of the PSC (adopted in Durban, South Africa, 9 July 2002), art 7(g).

116 Id, art 8(5).

117 See notably the communiqué for the PSC's 935th meeting (9 July 2020) on elections in Africa for the period from September to December 2019 and January to June 2020.

118 Communiqué for the PSC's 982nd meeting (25 February 2021) on elections in Africa for the period from July to December 2020 and those held, as well as those to be held, during the first quarter of 2021. 
Mauritius, Mozambique, Namibia, Seychelles, South Africa, Tanzania, Zambia and Zimbabwe. Since its inception, the ECF-SADC has also carried out capacity building programmes and deployed peer review and observer missions. The SADC Electoral Advisory Council advises member states on electoral matters in the region and develops mediation strategies to address conflicts in the pre- and post-election period. It also ensures that the recommendations of SADC electoral observation missions are implemented. The ECOWAS Network of Electoral Commissions is a platform for mutual assistance and peer exchange to promote best electoral practices in the region. The East African Community (EAC) also undertakes electoral observer missions.

SADC indicated in September 2020 that it was developing guidelines on election observation during pandemics. ${ }^{119}$ ECOWAS deployed observers for elections in Burkina Faso in November and Ghana and Niger in December. The EAC also conducted observer missions, notably for the Tanzanian election.

\section{African Governance Architecture}

The African Governance Architecture was adopted in 2011 by AU government leaders to facilitate cooperation among various stakeholders in good governance and democracy through the African Governance Platform. ${ }^{120}$ Entrusted with implementing AU shared values and the ACDEG, this platform consists of AU organs and RECs. It focuses on the exchange of information and the facilitation of dialogue among stakeholders in promoting democracy, including the conduct of free and fair elections.

\section{African Commission on Human and Peoples' Rights}

Article 49 of the ACDEG requires states to submit a state report on the implementation status of the African Charter to the African Commission on Human and Peoples' Rights. ${ }^{121}$ States are therefore required to report on the institutional, legal and normative framework of the conduct of elections.

The commission issued a statement on the conduct of elections during the pandemic, highlighting relevant state duties in the organization of elections in furtherance of the protection of human rights. ${ }^{122}$

119 "SADC develops guidelines for election observation during pandemics" (19 September 2020) SADC News, available at: <https://www.sadc.int/news-events/news/sadc-developsguidelines-election-observation-during-pandemics/> (last accessed 23 August 2021).

120 AU Executive Council decision EX.CL/Dec.499(XV) Rev.1 "Decision on the African Union Commission Strategic Plan 2009-2012 doc. ex.cl/501(xv)” (Executive Council's 15th ordinary session, Sirte, Libya, 1 July 2009), endorsed by the AU Assembly Assembly/AU/Dec.247(XIII) "Decision on the African Union Commission Strategic Plan 2009-2012” (AU Assembly's 13th ordinary session, Sirte, Libya, 3 July 2009).

121 ACDEG, art 49.

122 "Statement of the African Commission on Human and Peoples' Rights on elections in Africa during the COVID-19 pandemic" (22 July 2020), available at: <https://achpr.au. int/en/news/press-releases/2020-07-22/statement-african-commission-human-and-peoplesrights> (last accessed 9 September 2021). 


\section{MITIGATION AND SOLUTIONS: NATIONAL AND REGIONAL PERSPECTIVES}

An initial assessment of the predominant challenges faced by African states in their responses to electoral administration in the first year of the pandemic brings to light a number of pressing issues and opportunities of particular relevance to the region. First, responses are the preserve of the executive and do not result from a participative and transparent analysis of proportionality. Secondly, as a consequence of the dearth of checks and balances and the silence of constitutional and legal frameworks on force majeure limitations, responses are currently unenforceable. Thirdly, states and continental institutions are acting in silos, as responses and related efforts in monitoring, risk assessment and data availability are poorly coordinated across sub-regions and the continent. Fourthly, there is a lack of clarity in international law in guiding state obligations regarding derogations during emergencies.

\section{Consultation and consensus}

To acquire national ownership of the response adopted and buy-in from all relevant stakeholders, broader consultation with key actors is needed. Decision-making requires open engagement and collaboration with public health authorities, governance and legal experts, civil society organizations and all political actors, to promote acceptance and legitimacy of the recourse, and to allay tensions and risks of violent unrest. Inadequate dialogue regarding the postponement of elections in Ethiopia damaged political and public expectations and led to strife and escalating violence. ${ }^{123}$ In the Central African Republic, the Constitutional Court rejected a parliamentary proposal for a constitutional amendment to extend the term limits of the president and the National Assembly in response to the constitutional and power vacuum caused by the postponement of elections. The proposal had not been voted in Parliament, only signed by legislators. Instead, the court upheld that a decision would require "a consensual solution" based on an extensive national consultation exercise involving the opposition and civil society organizations. ${ }^{124}$

While the court has not provided guidelines on the scope and conduct of consultations, at a minimum, discussions will need to include a range of legal, technical and sanitary parameters for ensuring institutional continuity and respect for fundamental rights and freedoms, as well as a timeline for re-assessment. They will also entail inquiry into accessibility for those

123 "Joint statement of the Oromo Liberation Front and Oromo Federalist Congress on the \#COVID19 and postponement of the 2020 Ethiopian election" (3 April 2020) kichuu info, available at: <https://kichuu.com/joint-statement-of-the-oromo-liberation-frontand-oromo-federalist-congress/> (last accessed 23 August 2021).

124 "CAR court rejects bid to extend president mandate if polls delayed" (5 June 2020) Al Jazeera, available at: <https://www.aljazeera.com/news/2020/06/car-court-rejects-bidextend-president-mandate-poll-delayed-200605142249771.html> (last accessed 23 August 2021). 
particularly vulnerable to or affected by the disease, along with other modes of discrimination, using an intersectional approach, including a gender analysis. ${ }^{125}$ Moreover, consultations will invariably need to involve technological and security considerations. Significantly, the consultative process will need to be transparent, informing the electorate in advance of the findings, available solutions and the envisaged timeline. To enhance reach, government authorities could also rely on broader engagement with community and religious leaders who enjoy citizens' trust. ${ }^{126}$ Dialogue should also involve closer collaboration with capacity building actors, electoral support organizations and other relevant professional networks, for training and sensitizing poll station workers and the electorate for voting in crisis situations, leveraging their experience in past public health crises such as Ebola. ${ }^{127}$

\section{An enhanced role for the courts}

As courts have taken a more active role in electoral verifiability and justice in Africa in recent years, notably in Kenya and Malawi, a further examination of the role of the judiciary and legal remedies on electoral programming and management would serve to respond to the lacuna of checks and balances during health crises. The recent review by the Constitutional Court of the Central African Republic, described above, sets a promising example. In Uganda, a concerned citizen filed a suit in April 2020 at the High Court, requesting the court to postpone elections until the danger of the virus had been contained. The court did not address the petition. ${ }^{128}$ This nonetheless underlines citizens' reliance on the judiciary to protect the stability of the democratic system, particularly at such a time. The developing jurisprudence on adjudicating election petitions or election management issues warrants an urgent focus on the functions of courts amid the diverse legal traditions across African states, especially their role in reviewing and monitoring national consultations. In this regard, knowledge exchange among global and regional networks, such as the Global Network on Electoral Justice and the recently constituted Africa Electoral Jurisprudence Working Group, will be useful. ${ }^{129}$

125 See notably M Applegate and S Paasilinna "How to protect gender equality in elections during COVID-19" (28 April 2020, International Foundation for Electoral Systems), available at: <https://www.ifes.org/news/how-protect-gender-equality-elections-during-covid19> (last accessed 23 August 2021).

126 C Logan "Lessons from COVID-19 in Africa: Crisis and opportunity" (8 May 2020) Governance Link 15, available at: <https://www.aprm-au.org/wp-content/uploads/2020/ 05/APRM-GovernanceLink-Newsletter-May-Issue-8.pdf> (last accessed 23 August 2021).

127 A Banbury "Elections and COVID-19: What we learned from Ebola" (8 April 2020) Devex, available at: <https://www.devex.com/news/opinion-elections-and-covid-19-what-welearned-from-ebola-96903> (last accessed 23 August 2021).

128 "Coronavirus: Court asked to suspend 2021 Uganda elections" (13 March 2020) The Independent, available at: < https://www.independent.co.ug/coronavirus-court-asked-tosuspend-2021-uganda-elections/> (last accessed 23 August 2021).

129 See R Nackerdien and K Ellena "Elections on trial project: Inaugural meeting of the Africa Electoral Jurisprudence Working Group” (2 May 2019, International Foundation for 


\section{Regional integration and cooperation}

While the pandemic has seen the AU's prompt reaction in overseeing public health responses to the pandemic and highlighting the need for continental public health surveillance and joint funding, ${ }^{130}$ the AU has been slower in providing strategic leadership and coordination in respect of the impact of the pandemic on democratic governance and peace and security. Among the RECs, the ECOWAS Network on Electoral Commissions took some initiative by stocktaking and anticipating challenges to elections in the sub-region. ${ }^{131}$ The pandemic calls for increased coordination of regional and sub-regional actors regarding in-country mediation, election monitoring and countryspecific technical support. The AU Commission only enunciated its guidelines for the conduct of elections in the midst of the pandemic, over a year after the outbreak began, ${ }^{132}$ while other regional institutions have been more proactive. ${ }^{133}$ The PSC pointed to the need to accelerate the development of such guidelines. ${ }^{134}$ It will also be critical for the AU Commission to provide guidelines on remote long-term electoral observation and the revamping of its own observation missions in light of the pandemic and travel restrictions. It will also be compelling to investigate how regional mechanisms, such as those under the AU norm of unconstitutional changes of government, can be further used in the COVID-19 context for state compliance with international electoral obligations.

\section{Legal certainty}

Given the significant impact of the absence of legal consensus on applicable standards regarding the implementation of emergency measures in the

contd

Electoral Systems), available at: <https://www.ifes.org/news/elections-trial-projectinaugural-meeting-africa-electoral-jurisprudence-working-group $>\quad$ last accessed 23 August 2021).

130 The Africa Centres for Disease Control established an Africa Taskforce for Novel Coronavirus as early as 3 February 2020. See "Africa joint continental strategy for COVID-19 outbreak" (5 March 2020), available at: <https://au.int/sites/default/files/ documents/38264-doc-africa_joint_continental_strategy_for_covid-19_outbreak.pdf> (last accessed 11 September 2021).

131 "Impacts of the coronavirus pandemic on the upcoming elections in the ECOWAS region: Discussions and prospects" (15 April 2020, ECOWAS Network of Electoral Commissions), available at: <http://aceproject.org/ero-en/REPORT-VIDEOCONFERENCECOVID-19-IMPACTS-APR-2020.pdf> (last accessed 23 August 2021).

132 See above at note 108 .

133 See "Respect for democracy, human rights", above at note 92; "Guide to organising elections in times of pandemic" (2020, Organization of American States General Secretariat in collaboration with the Pan American Health Organization, in Spanish), available at: <http://www.oas.org/documents/spa/press/OEA-guia-para-organizar-elecciones-entiempos-de-pandemia.pdf> (last accessed 23 August 2021).

134 Communiqué for the PSC's 935th meeting (9 July 2020) on elections in Africa for the period from September to December 2019 and January to June 2020. 
context of elections, the African Court also needs to seize the opportunity to clarify legal uncertainties. ${ }^{135}$ In June 2020, the Pan-African Lawyers Union (PALU) filed a request for an advisory opinion from the African Court on states' obligations when conducting elections during pandemics. ${ }^{136}$ The advisory opinion was only issued in July 2021.137 The court emphasized state sovereignty and the primacy of domestic law in the decision to hold or postpone elections, including during the prevalence of emergencies, with the caveat of inclusive consultation. ${ }^{138}$ In formulating the legal standards regarding the limitation and suspension of rights during a pandemic, it reiterated the tenets of proportionality, ${ }^{139}$ and provided some remarks on pertinent mitigation measures, which align with guidelines issued by the African Commission on Human and Peoples' Rights and other human rights bodies. ${ }^{140}$ Most importantly, it deferred to domestic law on the conditions for postponement and the applicable standards in the event of a vacancy of power at the expiry of a term of office. ${ }^{141}$ The pandemic had brought to light the shortcomings of extant national legal frameworks and a lack of constitutional regulation in respect of the parameters of governance in crisis, notably the criteria for electoral deadlines and caretaker governments. ${ }^{142}$ The court, however, barely closed the gap on the legal contours for postponement, only conceding that these questions should (henceforth) be defined in legislation.

\section{CONCLUSION}

Elections are the cornerstone of representation and accountability in democratic governance. Elections held in Africa in 2020 unfolded as the pandemic

135 "Statement of the African Commission", above at note 122.

136 "PALU files request for an advisory opinion before the African Court on the guarantees for the effective protection of the right to participate in government in Africa, in the context of the COVID-19 pandemic" (2 June 2020, Pan African Lawyers Union), available at: <https://lawyersofafrica.org/wp-content/uploads/2020/06/PALU-Press-Release-FilesRequest-for-an-Advisory-Opinion-before-the-African-Court-EngFr.pdf> (last accessed 23 August 2021).

137 African Court "Advisory opinion on request no 001/2020 by the Pan African Lawyers Union (PALU) on the right to participate in the government of one's country in the context of an election held during a public health emergency or a pandemic, such as the COVID-19 crisis", available at: <https://www.african-court.org/cpmt/storage/app/uplo ads/public/60f/574/3a6/60f5743a61e75369142990.pdf> (last accessed 11 September 2021).

138 Id, paras 48, 52 and 53.

139 Id, paras 71-79.

140 Id, paras 80-84.

141 Id, paras 98-107.

142 See notably AK Abebe "Beating around the bush on the constitutional conundrum" (15 May 2020, International Institute for Democracy and Electoral Assistance), available at: <https://www.idea.int/news-media/news/beating-around-bush-constitutio nal-conundrum> (last accessed 11 September 2021). 
was in its upward trajectory. 2021 will be crucial in determining further impacts of state responses in electoral administration on human rights in the region and potential solutions for holding safe, inclusive, timely and free and fair elections amid pandemics. An analysis of preliminary responses shows that perennial tactics of political repression and crackdowns on civic space continue to characterize the African electoral landscape, and are further amplified in an environment clouded by the ostensible prioritization of public health concerns. An interrogation of international law indicates that electoral governance in emergencies needs to be guided by proportionality and special measures. State obligations relating to the promotion of democratic exercises are, however, not thoroughly articulated and emerging guidelines by regional bodies, international health authorities and electoral practitioners are helpful in informing state responses.

While electoral governance in crises is novel in most of the world, Africa is more exposed to such threats as a result of enduring peace and security challenges (notably in the Sahel) or public health emergencies such as Ebola. It is important that regional responses are reinforced and harmonized, and norms and standards clarified so that future crises can be responded to, while respecting human rights and democratic principles. This will primarily necessitate the development of rigorous consultative processes in electoral governance across African countries. Courts can help in defining the conditions for such consultation and ensure that political processes fulfil legal requirements as well as human rights standards in the conduct of elections. Crucially, enhanced electoral governance also needs a domestic law definition of the parameters for the scheduling of elections, the legal standards for postponement and the applicable standards in the event of a vacancy of power. It will also require further efforts to operationalize and coordinate regional mechanisms in governance, democracy and human rights on the continent.

\section{CONFLICTS OF INTEREST}

None 